\title{
Teenagers' experiences of sexual health dialogue in the rural villages of the Vhembe District, Limpopo Province
}

\author{
Authors: \\ Lebese R. Tsakani ${ }^{1}$ \\ Mashudu Davhana- \\ Maselesele ${ }^{2}$ \\ Larry C. Obi ${ }^{3}$ \\ Affiliations: \\ ${ }^{1}$ Department of Advanced \\ Nursing Science, University \\ of Venda, South Africa \\ ${ }^{2}$ Science and Technology, \\ North-West University \\ (Mafikeng Campus), \\ South Africa \\ ${ }^{3}$ Academic Affairs and \\ Research, Walter Sisulu \\ University, South Africa \\ Correspondence to: \\ Lebese Tsakani \\ Email: \\ rachel.lebese@univen.ac.za \\ Postal address: \\ PO Box 3198, Giyani 0826, \\ South Africa \\ Dates: \\ Received: 07 Oct. 2009 \\ Accepted: 11 Aug. 2010 \\ Published: 23 Feb. 2011 \\ How to cite this article: \\ Lebese, R.T., Davhana- \\ Maselesele, M. \& Obi, \\ L.C., 2011, 'Teenagers' \\ experiences of sexual \\ health dialogue in the rural \\ villages of the Vhembe \\ District, Limpopo Province', \\ Health SA Gesondheid \\ 16(1), Art. \#502, 10 pages. \\ doi:10.4102/hsag.v16i1.502
}

(C) 2011. The Authors. Licensee: OpenJournals Publishing. This work is licensed under the Creative Commons Attribution License.
Dialogue with teenagers about sexual health is of global concern, as it is found mostly to be minimal, if not absent. This limitation is influenced by the cultural values, beliefs and norms of teenagers. To a great extent, culture influences which and how sexual health issues can be discussed between teenagers and adults. The purpose of this study was to explore and describe teenagers' experiences of sexual health dialogue in the rural areas of the Vhembe district in Limpopo province, South Africa. A qualitative, explorative, descriptive and contextual research approach was used. Data were collected by means of in-depth, individual interviews and focus-group discussions. A purposive sampling method was used to select the 57 participating teenagers, based on criteria that were set. The findings of the study indicated that there was minimal dialogue between adults and teenagers about sexual health. Most teenagers reported that they learned about issues related to sexual health from friends, the media, initiation schools and relatives who, most often, were aunts. It was also noted with concern that the teenagers always equated sexual health to the act of intercourse and that no attention was paid to other aspects of sexual health. Recommendations to improve the current situation were made.

Dialoog met tienerjariges rakende seksuele gesondheid is ' $\mathrm{n}$ wêreldwye probleem omdat daar gevind is dat dit meestal minimaal is of glad nie plaasvind nie. Hierdie beperking word beïnvloed deur die tienerjariges se kulturele waardes, oortuigings en norme. Kultuur beïnvloed in 'n groot mate watter seksuele gesondheidsake tussen tienerjariges en volwassenes bespreek kan word, en hoe dit gedoen kan word. Die doel van hierdie studie was om tienerjariges se ondervindings van seksuele gesondheidsdialoog in die landelike gebiede van die Vhembedistrik in die Limpopo-provinsie van Suid-Afrika te ondersoek en te bespreek. 'n Kwalitatiewe, ondersoekende, beskrywende en kontekstuele navorsingsbenadering is gevolg. Data is versamel deur middel van grondige individuele onderhoude en fokusgroep-besprekings. 'n Doelbewuste steekproefmetode is gebruik om die 57 deelnemende tienerjariges op grond van bepaalde kriteria te selekteer. Die bevindings van die studie het aangedui dat daar minimale dialoog oor seksuele gesondheid tussen tienerjariges en volwassenes is. Die meeste tienerjariges het gerapporteer dat hulle by vriende, die media, inisiasieskole en familielede, meestal ' $n$ tante, van seksuele gesondheid geleer het. Daar is met kommer opgemerk dat tienerjariges seksuele gesondheid aan die daad van omgang gelykstel en dat geen aandag aan ander aspekte van seksuele gesondheid geskenk is nie. Aanbevelings ter verbetering van die situasie is gemaak.

\section{Introduction and background}

Dialogue with teenagers about sexual health is of importance worldwide, especially because of the HIV and AIDS pandemic, increased rates of sexually transmitted infections (STIs), a high percentage of teenage pregnancies and parenthood, and decreased levels of contraceptive use amongst the youth. The rate of sexual activity amongst teenagers is said to have increased by $56 \%$ amongst boys and $73 \%$ amongst girls. Most boys are also reported to have had sexual intercourse before the age of 18 years (Cebekhulu, Bekisiska \& Erulkar 2001:10). Unplanned teenage pregnancies are also said to be high: approximately one million girls become pregnant each year (Cebekhulu et al 2001:10). Previous studies on the sexual behaviour of African students indicate that by the age of $18,10 \%$ to $24 \%$ of Black girls and $18 \%$ to $69 \%$ of Black boys have already had sexual intercourse. In the same study, $75 \%$ of Grade 10 to Grade 12 learners were also found to be sexually active, whilst $30 \%$ of them had had an average of three partners and nine sexual encounters in the previous year (Grobler et al. 2007:36). It is noted that teenagers experiment with and explore especially sexual intercourse, which exposes them to risky sexual practices, hence the need exists to establish how elders enter into dialogue with them, as this might be the best way of giving correct and relevant information so that they can make informed decisions about 
their sex life. An estimated 74\% of involuntary sexual activity (coercion) is reported by girls younger than 14 years and 13\% of females aged 15 years -19 years are reported to have been sexually abused (Kalmus et al. 2003:87). Sexual abuse has also been reported in males; in the same study, about $25 \%$ of men reported having been sexually abused before the age of 13 years. In early 2002, approximately 40 men reported having been sexually abused by Roman Catholic priests as children and teenagers (Adams \& East 2002:202). This study exposed the vulnerability of teenagers and children to STIs, including HIV and AIDS, and to teenage pregnancy and teenage parenthood, specifically because a person in an authoritative position can force them to do things against their will, and their ability to negotiate sex is weak (Adams \& East 2002:202). In South Africa, studies have also revealed that most of the girls participating in the research were forced to have sex against their will or were raped (Jewkes et al. 2001:740). It is therefore assumed that if teenagers are engaged in sexual health dialogue, they will be better able to identify actions that may lead to their being molested or raped, because they will have information on how to identify people who want to misuse them. Sexual health dialogue will also give them a platform on which to discuss issues such as rape openly.

Sexually active teenagers often engage in short-lived relationships. Reports show that sexually active teenagers aged between 13 years and 19 years have a history of having had four or more successive sexual partners (DicksonTetteth \& Foy 2000:3). Teenagers are mostly reported to have been sexually involved for less than a year before visiting a health care provider, whilst few teenagers had visited a health care provider a year or more after having engaged in sexual intercourse (Dickson-Tetteth \& Foy 2000:3). These delays are normally caused by a lack of information about services available, fear of adult disapproval, unfriendly health service providers and concerns by teenagers about the side effects of contraception (Dickson-Tetteth \& Foy 2000:3). Peers are therefore reported as being the predominant source of information regarding issues of sexuality, as well as the visiting of family planning services, whilst parents and teachers rank lower (Mfono 1998:182). This might be an indication that dialogue with teenagers about issues of sexual health is inadequate and that there is a need to develop new ways of promoting dialogue about sexual health with them.

In Britain, low socio-economic status, poor educational achievement and peer influences were found to be risk factors for teenage parenthood (Ingham \& Stone 2002:191). The social norms of the individuals or groups with whom the adolescent is connected, or with whom they interact, affect their sexual behaviour. If teenagers have parents, friends and partners with high moral values, they are more likely to delay sexual intercourse and pregnancy than adolescents who have parents, friends and partners with low morals (Kirby 2001:277). Cultural beliefs and attitudes also dominate the way of life in rural areas, influencing how teenagers relate to their parents, teachers and elders in the community. Values and norms guide what can be discussed between different age groups (Mfono 1998:124). The extent to which issues of sexual health are discussed between different age groups is therefore also determined by their cultural practices. Mfono
(1998:36) mentions the difficulties that parents experience in communicating with their children about sexual matters. Parents usually do not view their children as adults who are ready to contemplate or discuss sexual involvement. It has also been found that the information that parents give to their children regarding sexual matters is inadequate to equip teenagers to face the pressures regarding sexual issues (Mavundla \& Williams 1999:62). It is therefore assumed that dialogue with teenagers, in this case specifically in the rural areas of the Vhembe district in Limpopo province, could be inadequate, given the influence that culture has on what is considered to be acceptable topics for discussion or ways of discussing sexual health with teenagers.

\section{Problem statement}

One of the authors (L.R.T.) is a lecturer and frequently accompanies students on clinical training and community visits. During these visits, the author became aware of a high rate of STIs, pregnancies and termination of pregnancies amongst teenagers. This is an indication that the methods employed to reduce teenage pregnancies and STIs may not be effective and that teenagers may not have enough information about healthy sexual behaviour available to them. Lack of knowledge exposes teenagers to STIs such as HIV and AIDS, as well as teenage pregnancy and parenthood. Hence it was deemed necessary to explore teenagers' experiences of sexual health dialogue with parents or teachers in the rural villages of the Vhembe district in Limpopo province.

\section{Objectives of the study}

The objectives of the study were as follows:

- To identify how dialogue was conducted between teenagers, parents and teachers in the Vhembe district.

- To describe the experiences of teenagers in relation to sexual health dialogue with parents and teachers in the Vhembe district.

- To identify the role of cultural practices in sexual health dialogue between teenagers, parents and teachers in the Vhembe district.

- to make recommendations based on the results of the study.

\section{Significance of the study}

This study uncovered some socio-cultural perspectives influencing sexual health dialogue amongst teenagers, parents and teachers and possible solutions as to how such issues could be addressed. It is expected that the findings will inform the review and implementation of sexual and reproductive education, leading to improved sexual health dialogue between adults and teenagers.

\section{Literature review}

\section{Meta-theoretical assumptions}

Meta-theory is defined as the assumptions that are made about reality (Brink 2000:28). The researcher's point of departure was the assumption that teenagers are human beings with sexual needs that need to be fulfilled. Teenagers are also unique beings who can make their own choices and 
need to make informed decisions regarding the fulfilment of these needs. Educating teenagers about sexuality, particularly by parents, teachers and peers, is of vital importance in assisting them to make informed decisions about sexuality. The researcher (L.R.T.) believes that the primary socialisation of children starts at home, where parents have the role of educating their children about issues of sexual health. Secondary socialisation occurs at schools, where teachers have the role of educating teenagers. The teenagers will then internalise what they have been taught and this will determine the decisions that they make about sexual involvement.

\section{Theoretical assumptions}

This study was conceptualised within Leininger's Sunrise Trans-cultural Health Care Model (Leininger 1991:30) and the goal of this theory is to provide cultural-congruent care. The model takes individuals and groups into consideration, as well as their beliefs and value systems, and these specific cultural practices form the basis for, or the means through which satisfactory health care can be delivered.

\section{Definition of concepts}

The concepts central to this study are defined as follows:

- teenager

- parent

- teacher

- sexual health

- sexual health dialogue.

Teenager: In this study, a teenager is a male or female aged 13 years - 19 years who is attending school and has an intimate relationship with a person of the opposite or same sex.

Parent: A parent in this study is any person who is the parent of a child aged 13 years - 19 years, or the parent of a child who has given birth during her teenage years, or the parent of an HIV-positive teenager.

Teacher: In this study, a teacher is an educator who has the responsibility of teaching life skills, guidance or sexuality issues.

Sexual health: Sexual health is the ability to express one's sexuality free from the risk of STIs, unwanted pregnancy, coercion, violence and discrimination. It implies being able to have an informed, enjoyable and safe sex life, based on a positive approach to sexual expression and mutual respect in sexual relations.

Sexual health dialogue: This is a two-way conversation about issues of sexual health between teenagers and parents and/or teachers.

\section{Research design \\ Research approach and method}

A qualitative, explorative, descriptive and contextual approach was used for this study. The study strove to understand the phenomenon from the perspective of the teenagers, hence the research was conducted inductively. People were studied in their setting in order to discover the social world of cultures and languages by observing and talking to them (Halloway \& Wheeler 2002:17). The researcher used main questions as a point of departure and further questions that emanated from the discussion. Participants narrated their experiences and these experiences were reflected in words and quotations that were used to emphasise various aspects that were described (Burns \& Grove 2001:61; Kvale 1983:175; Polit \& Hungler 2004:50; Mouton \& Marais 1990:43,44) The experiences of teenagers were explored and then described within the context of the rural villages of the Vhembe district in Limpopo province, South Africa.

\section{Population and sampling}

The population for this study was all teenagers in the Vhembe district of Limpopo province (Brink 2000:132). Villages with high statistics of teenage pregnancies and STIs were sampled purposefully. Four villages in the Vhembe district were selected for this study and a purposive sample of teenagers between the ages of 13 years and 19 years was used. Only teenagers involved in an intimate relationship with a person of the opposite sex or same sex, who had a child or were pregnant, were interviewed. Two recruiters were used to select participants for the study, based on the criteria given. The researcher (L.R.T.) met the recruits, consent was given and the date and venue for the interview were agreed with the participants. A total of 57 teenagers were sampled. The total number of participants was determined by data saturation.

\section{Data collection}

The researcher collected data through in-depth, individual interviews and focus-group discussions. Fourteen teenagers were involved in in-depth, individual interviews and 43 in focus-group discussions. Data were audio-recorded, and field and observational notes were taken. The central question that directed the interviews was: 'Can you please tell me your experiences of sexual health dialogue with parents and teachers?' This question was translated into Xitsonga for the participants to make it easier for them to understand and participate (Xitsonga translation: Ni hlamusele hi ku vulavurisana na vatswari na mathicara hi timhaka ta masangu). Paraphrasing and probing, follow-up questioning was done to give the discussions more depth.

\section{Data analysis}

Data analysis was done concurrently with data collection (Cresswell 1994:142). Data were transcribed and then translated verbatim from Xitsonga into English by a language practitioner. The recorded information was also compared with the transcribed data to avoid omissions. Analysis was done according to Tesch's eight steps of analysis (as cited in Cresswell 1990:142). Topics were then listed and clustered, a final decision on the abbreviation for each category was 
made and the code was alphabetised. The data that belonged to each category were assembled in one place, preliminary analysis was performed and recoding was done (Cresswell 1990:142). A literature control ensured that there was a good fit between the data and relevant literature, providing a link between previous research and the present research (Mdluli 2005:50).

\section{Ethical considerations}

Permission to conduct this study was obtained from the Department of Education and Culture, the chief of the villages where data was collected, and school governing bodies. Ethical clearance from the University of Venda was given and an oral presentation was made to the University Ethics Committee. Particular care was taken to observe all ethical requirements in view of the participants' age and vulnerability.

Privacy is an individual's right to determine the time, extent and general circumstances under which personal information will be shared or withheld from others (Burns \& Grove 2001:196). Participants' private information was not shared without the individual's knowledge or against their will. The researcher ensured that the participants did not lose their dignity, friendship or employment in the course of the study. Confidentiality was ensured by not allowing people outside of the research team access to raw data. Participants' names were kept anonymous by using code names during interviews and filing of raw data. The selection process of

\begin{tabular}{|c|c|c|}
\hline Strategy & Criterion & Application \\
\hline \multirow[t]{5}{*}{ Credibility } & $\begin{array}{l}\text { Member } \\
\text { checking }\end{array}$ & $\begin{array}{l}\text { - Accurate description of teenagers' } \\
\text { experiences } \\
\text { - Data verification with participants to } \\
\text { ensure that data was captured properly } \\
\text { - Use of audiotapes and field notes }\end{array}$ \\
\hline & $\begin{array}{l}\text { Prolonged } \\
\text { engagement }\end{array}$ & $\begin{array}{l}\text { - In-depth interviews with follow-up } \\
\text { questions and probing to ensure longer } \\
\text { contact } \\
\text { - Rapport established with participants } \\
\text { and use of participants' language to } \\
\text { ensure extended period of engagement }\end{array}$ \\
\hline & Reflexivity & $\begin{array}{l}\text { - Field journal kept throughout, reflecting } \\
\text { daily schedule, frustrations, and } \\
\text { researcher's thoughts }\end{array}$ \\
\hline & $\begin{array}{l}\text { Data } \\
\text { triangulation }\end{array}$ & $\begin{array}{l}\text { - Researcher used different data } \\
\text { collection methods and compared them }\end{array}$ \\
\hline & Peer review & $\begin{array}{l}\text { Research process discussed with } \\
\text { supervisor and colleagues } \\
\text { - Researcher trained in qualitative data } \\
\text { collection methods }\end{array}$ \\
\hline Transferability & $\begin{array}{l}\text { Thick description } \\
\text { of participants and } \\
\text { context }\end{array}$ & $\begin{array}{l}\text { Dense description of background } \\
\text { information of participants, research } \\
\text { context and technique used to select } \\
\text { participants }\end{array}$ \\
\hline Dependability & $\begin{array}{l}\text { Thick description } \\
\text { of methodology }\end{array}$ & $\begin{array}{l}\text { - Research methods adequately described } \\
\text { - Code and recoding done } \\
\text { - Methodology assessed by expects }\end{array}$ \\
\hline Neutrality & $\begin{array}{l}\text { Prolonged } \\
\text { engagement }\end{array}$ & - Use of in-depth interviews \\
\hline
\end{tabular}

participants was done fairly as each participant fitting the criteria had a chance of being selected and all participants were protected against emotional harm. Focus-group discussions were conducted within walking distance of the participants' homes, and in-depth, individual interviews were conducted in the participants' homes. The participants, therefore, did not incur any financial expense (Burns \& Grove 2001:196; DENOSA 1998:2.3).

\section{Trustworthiness}

Guba's model (in Lincoln \& Guba 1985:216-217) for ensuring and assessing trustworthiness was employed in this study (see Table 1).

\section{Results and discussion}

Data were analysed using Tesch's eight steps of data analysis (in Creswell 1990:145). Table 2 provides an analysis of the themes, categories and sub-categories that emerged from the analysis of raw data.

\section{Learning about sexual health}

Learning about sexual health emerged as a theme from the data and reflected that teenagers acquired knowledge of sexual health from different sources. It was also noted, with concern, that parents were not mentioned as the main source of information about sexual health. The categories identified from the theme were, (1) media influence, (2) peers,family or friends and (3) a cultural context.

\section{Media influence}

During interviews, the media was cited as the main source of information on sexual health, especially during the new era of democracy in South Africa where there is freedom of expression and easy access to television, magazines and even pornographic films or videos. The participants reported learning about sexual health from the media in, (1) television and film and (2) magazines and pornographic pictures.

\section{Television and film}

Teenagers indicate that television, films and other media are the leading sources of information about sex and sexuality (Malcolm 2007:6). Data from this study showed that the participants learned about sex from television, especially films. Teenagers reported that some films on television, especially those that were screened late at night like Emanuelle were very informative to them. These films were sometimes discussed with same-sex peers at school, who would add more information based on their different experiences, or participants would even try to implement what they had seen with their partners. One participant had the following to say:

'You know, I have learnt a lot from television about sex, in some of the programmes on e.tv; there is this film called Emanuelle where sexual issues, especially intercourse, is showed A up to Z. You know, we watch it at night when [the] old people are asleep. 
TABLE 2: Analysis of themes, categories and sub-categories regarding teenagers' experiences of sexual health dialogue.

\begin{tabular}{|c|c|c|}
\hline Themes & Categories & Sub-categories \\
\hline \multirow{3}{*}{$\begin{array}{l}\text { Learning } \\
\text { about sexual } \\
\text { health }\end{array}$} & Media influence & $\begin{array}{l}\text { - Television and film } \\
\text { - Magazines and pornographic pictures }\end{array}$ \\
\hline & $\begin{array}{l}\text { Information from } \\
\text { peers, family and } \\
\text { friends }\end{array}$ & $\begin{array}{l}\text { - Peer pressure } \\
\text { - Teaching by family members or siblings } \\
\text { - Teaching at school }\end{array}$ \\
\hline & $\begin{array}{l}\text { Vatsonga cultural } \\
\text { influence }\end{array}$ & $\begin{array}{l}\text { - Culture regards discussion of sexual issues } \\
\text { as disrespectful } \\
\text { - Graduation from traditional initiation } \\
\text { schools }\end{array}$ \\
\hline \multirow[t]{2}{*}{$\begin{array}{l}\text { Teenagers' } \\
\text { views about } \\
\text { sexual health }\end{array}$} & $\begin{array}{l}\text { Views on the person } \\
\text { talking to them } \\
\text { about sex }\end{array}$ & $\begin{array}{l}\text { - A person discussing sexuality is perceived } \\
\text { as being wrong or corrupt } \\
\text { - Adult information is reliable and correct }\end{array}$ \\
\hline & $\begin{array}{l}\text { Views about how } \\
\text { exual dialogue can } \\
\text { be initiated }\end{array}$ & $\begin{array}{l}\text { - Discussions should start early at home } \\
\text { - Should be taught to them by a familiar } \\
\text { person }\end{array}$ \\
\hline
\end{tabular}

In that programme you can see how a woman is handled when having sexual intercourse and this makes you to be prepared when you want to have sex with the woman. Hhhhh ... the television shows step by step how this is done. You know sometimes I feel it is too much as when you are watching; you get these feelings aaaa! [laughs] ...you know what I mean. They normally play this programme late at night. I am telling you, you can't watch it with somebody older than you. It is too explicit.'

(Participant)

Another commented:

'Heee! I saw one film at my friend's house; it was about people doing it, eeee! You know what I mean. They show you how people do it, they don't hide anything, it even gives you those feelings and if you are with a girl, you just want to do it.'

(Participant)

Exposure of children to sex in television has increased by $400 \%$ in the United States from 1976 to 1996. Such exposure has been found to affect adolescents' moral judgement, which is said to have contributed to the high level of pregnancy amongst the youth in the United States (Answers. com 2007). In a study on the youth's perceptions of sexuality in Limpopo, South Africa, television was found to influence teenagers' sexuality because of their perception that whatever was portrayed on television was normal or correct (Maluleke 2007:11).

In this study, the results show that the teenagers obtained information about sex from television and film, and this information was sometimes positive and sometimes negative. This means that parents should be aware of the type of information that their teenage children come into contact with, so that they can guide them. It is also important for them to keep the lines of communication open, as this would enable teenagers to discuss with them what they have seen.

\section{Magazines and pornographic pictures}

In a study by Hassan and Creatsas (2000), television and other media communication were identified as the main source of information and misinformation about sexual health for teenagers. The media was said to be providing correct information, particularly when a health issue was addressed by a health professional. However, misinformation was also said to be given by the media through advertising or giving the wrong impression about certain issues. In another study, arousal of sexual desire was also described, as teenagers reported that there were situations that made controlling their sexual desires difficult (like sitting next to their partners, caressing each other or watching a movie together) (Maluleke 2007:14).

The teenagers in this study also cited magazines and pornographic pictures as means through which information was acquired about sexual issues. The participants mentioned magazines such as True Love and Bona, in which sexual issues are discussed and they thought that these columns were informative. However, they also believed that the media lacked information on contraception, except for information about the use of condoms to prevent infections. The respondents felt that the media could be a good source of information regarding sexual health, especially on issues of contraception. One teenager made the following observation:

'You know, there are books and magazines which show positions and everything about sexual intercourse and one needs to practise these things, otherwise you will appear to be a fool, so in order to be clever one needs to read about this things in the book. Do you think there can be a person who can teach you about sex? Ha! That will be the day. You know with magazines, you do not have to be shy as you can read it alone in privacy without interference from anybody and this makes me relax and understand the contents much easier.'

(Participant)

Another participant added:

'I so wish that there was enough information about issues of sexual health and contraceptives in the media; this could reduce the rate of teenage pregnancy. You know this can also reduce HIV and AIDS. Information about condoms is available but it is not enough, as most of the teenagers use them without understanding.'

(Participant)

Our results show that it was apparent that teenagers relied on the media for most of their information about sexual health. If television is their main source of information, there could be a great deal of misinformation provided, because different programmes are screened on television for different purposes. It is therefore noted, with concern, that sexually active teenagers have access to information that can be insufficient and misleading and this can expose them to sexual health risks.

\section{Information from peers, family and friends}

Different situations in which teenagers found themselves were mentioned as sources of information for them. Almost none of the participants cited parents as sources of information. The sub-categories that emerged from this category were, (1) peer pressure, (2) teaching by family members and (3) teaching at school.

\section{Peer pressure}

A study in Thailand showed that boys were regarded as 'smart' and admired when they recounted their stories of sexual performance and conquests to their peers. The Thai 
teenagers were found to have a heightened sexual awareness and curiosity, and gaps in sexual knowledge and life skills (Vuttanont et al. 2006:2072). In a study conducted in South Africa, Wood, Maforah and Jewkes (1998:8) also reported that peer pressure was a factor that influenced teenagers to engage in sexual relations or sexual intercourse. Being sexually experienced allowed students to be recognised as members of the 'in' (socially acceptable) group. Those not included had been sent away when discussing issues of sex because of the implication that they would not contribute to the conversation, or that they could repeat the secrets of the 'in' group (Wood et al. 1998:8).

The same study also reported that its female participants were found to be giving incorrect and misleading information about sex to their peers. Information given included statements such as 'sex was painful', 'sex did not feel right', 'during sex, the man came on top of you', or 'sex was done at night'. Inexperienced teenagers in the study indicated that this information was misleading with regard to what to expect when they were to have intercourse. Wood et al. (1998:12) also showed that some teenagers participated in sex out of their own curiosity. In another study, white female teenagers who were virgins and had a friend who was not a virgin were found to have a three-fold greater chance of engaging in or initiating sexual intercourse within 3 years (Billy \& Undry 1985:30). Maluleke (2007:11) found in her study that peers had a major influence, both negative and positive, on youths' sexuality.

Our results showed that peers were a source of information on sexual issues. The participants indicated that most of the time they discussed sex with their peers and during these discussions, they needed to give an account of their sexual experiences, and if they had none, they were regarded as 'fools'. They were also encouraged to have intercourse so that they could be regarded as more socially acceptable. The respondents reported that these practices and/or conversations put a great deal of pressure on them as they often started engaging in sexual intercourse because they wanted to gain the approval of their peers. One teenager observed the following:

'There is a lot that we talk about as teenagers and most of the time we talk about sexual health issues. When we talk with friends about sexual intercourse I normally lie about it, as I have not experienced it, so that my friends do not think that I am stupid. This often makes me feel inadequate and I really want to do it so that I can also feel important. Friends can isolate you if they are aware that you have not experienced what they know. So telling a lie makes you to belong to a group.'

(Participant)

It is also noted with concern that most of the time, teenagers share information that they are unsure of themselves. Teenagers also do not always use precautionary measures and this may expose them to STIs, including HIV and AIDS. It has also been observed that the some teenagers can be a good source of information for their peers if they have access to correct information.

\section{Teaching by family members}

The respondents expressed how they were informed about sexual health by their siblings. It was noted, with concern, that the type of information that was given to teenagers was only about sexual intercourse. More important, relevant information about the use of condoms or other forms of contraception was not shared with them by their siblings. Research indicates that children prefer to be taught about issues of sexual health by their peers rather than their parents. Children have reported that they often felt embarrassed when they talked to parents about issues of sexual health (Ogle, Glasier \& Riley 2008:286). It has been noted in the same study that girls are more likely to discuss issues of sexual health with their mothers than with their fathers (Ogle et al. 2008:287). The view of one participant was expressed as follows:

'You know, things do happen in the bedroom. My elder brother used to show me how it is done [laughs] I mean with the girl. He used to show me as demonstration on the bed using a pillow. He even showed me how to romance a girl before intercourse and he always said that he does not want me to be a fool. He even explained to me how enjoyable sex is and I just tried it and the girl I tried with fell pregnant and she has a child. It is disturbing because I did it without protection, yoo! Life is tough [laughs].

(Participant)

\section{Teaching at school}

Most of the teenagers that were interviewed reported that teachers taught them a great deal about sexual issues at school. School was also the place where most of the information related to sexual health could be obtained. It was found that learners were comfortable with female teachers as they were said to be patient and provided them with the information they required. However, some of the teenagers did not feel comfortable discussing issues of sexual health with teachers; some of them said that they feared being labelled, as shown in the following comment:

'I have learnt a lot about sexual health from school. Our ma'am is very good and patient. She taught us a lot even about rape and how to report to the police. My problem is that when you ask more questions in class they always laugh at you and this makes us be afraid and not participate. When I started menstruating I did not have problems as she had already taught us. Hey, she really helped me.'

(Participant)

Despite the feedback from participants, schools have been reported to be ill prepared to teach sex education. The curriculum in the United Kingdom is said not to put pressure on the schools to teach sexual health, because there are no examinations and sexual health is not a compulsory study area for trainee teachers. This means that sexual health education in schools does not have much impact and does not have a positive effect on teenagers, hence teenage pregnancy remains high in the UK (Evans \& Tripp 2006:96). This is also confirmed by data from participants that sex education is a non-examination subject, hence little emphasis is given to it.

\section{Vatsonga cultural influence}

Participants indicated that culture played different roles in sexual health dialogue. Culture was said to influence the way 
in which teenagers discussed issues of sexual health with their parents. The role of culture in sexual health dialogue is discussed under the following sub-categories, (1) culture regards discussion of sexual issues as disrespectful and (2) graduation from traditional initiation schools.

\section{Culture regards discussion of sexual issues as disrespectful}

Previous studies show that discussing sexuality is very difficult, especially between parents and children. Sexuality is seen as something that cannot be talked about in public but should rather be discussed with peers (Maluleke 2007:9). Research conducted in Kenya (Mbugua 2006:1083) describes society in that area and other parts of sub-Saharan Africa as having similar cultural barriers that deter members of one group (parents) from discussing matters of sex with members of another age group (children or immediate juniors) or people of the opposite sex. In the same study, it was mentioned that this practice also existed in modern, educated families who had knowledge about HIV and AIDS (Mbugua 2006:1083). European Christian values were also said to have an influence on sex education, as several mothers in the study believed that a good Christian should use clean language in explaining sexual matters and therefore use metaphors which they hoped their children would understand (Mbugua 2006:1088).

It is assumed that, to some extent, culture and religious factors do influence how parents and/or teachers communicate with teenagers about sex and that most of the time, these factors inhibit dialogue more than encourage it. Peer discussions have a significant impact on education. This means that it is very important for teenagers to have correct information to share amongst themselves.

The participants in this study reported that it was difficult to talk to parents about sex because this was regarded as 'taboo'. Discussing sex with elders was also regarded as disrespectful. It was mentioned that, according to culture, the aunts in the family, not the parents, are expected to talk to teenagers about sexual health. One respondent commented:

'I don't actually know how I can start a dialogue about issues of sexual health with my parents, as this is seen as disrespectful, as one has been taught not to speak to adults about sex or anything that is vulgar, so I do not expect my parents to talk to me about sex. A person needs to be clever and look for information yourself [phanda]. You know, most of the time when you ask questions about sex to parents, they think that you are already engaging in sexual intercourse.'

(Participant)

\section{Graduation from traditional initiation schools}

Previous studies show that much education on sexual issues is provided when young girls and boys are initiated (undergo rites of puberty). Sponsors (mentors of initiates) are permitted to give comprehensive sex education to initiates. Candid sex talks that are reinforced in songs with explicit sexual language are taught to initiates. Because dancing to these explicit songs is part of learning, dance becomes a means through which sex education is reinforced. After graduation, some of the teenagers marry, because completing inititation is perceived as readiness for marriage (Mbugua 2006:1082). A study by Maluleke (2007:13) showed that initiation had both positive and negative effects: some participating teenagers thought that going through puberty rites (initiation) helped them to remain virgins, whilst on the other hand, some teenagers felt that puberty rites were performed too late as they had already been sexually active and there was nothing new to learn (Maluleke 2007:13).

Mulaudzi (2007:34) also describes how the focus on sex education in initiation schools amongst the Vhavenda people is emphasised. The researcher explains how girl initiates are warned against engaging in sex at an early age. At the same time, the girls are also taught how to have sexual intercourse, which can be viewed as contradictory, because it might influence them to experiment with sex.

It has been observed from the data and literature reviewed, regarding the role of initiation schools in sex education, that some form of sex education does take place in these schools and this has been found to have both negative and positive effects. Such education, given in the form of song, dance and story-telling, can be powerful if the people doing the teaching are well informed and if it is well structured to cover all aspects of sexuality.

Our study showed that teenagers obtained much information about sex during initiation, where they were taught how to relate to people of the opposite sex, especially during sexual intercourse, and how they should respond. This caused teenagers to be inquisitive and eager to experiment with sexual intercourse. They indicated that in most instances, teenagers became pregnant after attending initiation schools. One participant commented as follows:

'You know, it is so exciting in initiation schools; you don't have to be ashamed of anything, people just mention everything even private parts by name. The songs are also full of vulgar language and we are told that we are now adults, and when we come out of initiation, we feel that we have grown up and we must do what adults do without questioning it.'

(Participant)

\section{Teenagers' views about sexual health dialogue}

Teenagers' views about sexual health dialogue was the second theme gained from the data and showed that the study participants had both positive and negative responses about the person engaging with them in sexual health dialogue. The categories that emerged from this theme were, (1) views on the person talking to the teenagers about sex and (2) views about how dialogue on sexual health can be initiated.

\section{Views on the person talking to teenagers about sex}

Teenagers expressed different views regarding the person talking to them about sex. This was further sub-categorised as follows, (1) a person discussing sexuality is perceived as being wrong and/or corrupt and (2) adult information is reliable and correct. 


\section{Persons discussing sexuality are perceived as being wrong and/or corrupt}

European Christian principles imposed on Kenyans were also found to have a negative impact on sexuality education (Mbugua 2006: 1083). The use of foul language was discouraged, and most Kenyan Christians took offence at the mention of genitals or sexual intercourse. This tended to inhibit parents, teachers and leaders from talking openly about sex, as it was regarded as morally wrong and they feared being labelled as promiscuous (Mbugua 2006:1083). Culture and religion play a role in influencing people's views about the person talking to young people about sexual health issues. In the United Kingdom, it was found that the majority of teachers were extremely uncomfortable with the idea of teaching sexual health. This was caused by the cultural taboo attached to sexuality and in particular, adolescent sexuality. The legality of the specific curricular content was also found to be a problem for teachers (Evans \& Tripp 2006:96).

The teenagers interviewed in this study commented that they regarded the person who always talked to them about sex as being corrupt, or they thought that that person would like to rape them if he was a male. The respondents said that most of the time when people wanted to have intercourse with them, they talked about sex playfully in the hope that they could initiate it with them. They believed that because there appears to be a high level of child sexual abuse in South Africa, they were always sceptical about a person engaging in sexual dialogue with them. Some of the teenagers reported that people who were using drugs also used sexual talk to lure them, so this resulted in their viewing a person talking about sex with suspicion. One participant said:

'Ma'am, you know most of the time, if an adult talks to us about sex, they have a motive behind it. Most of these adults have low morals and can easily rape or abuse you, that is why we always question the motive when an adult talks to us about sex especially if that person is a stranger. Ma'am, sometimes adults talk about sex and give a person drugs so that they can rape you; hey, it is dangerous.'

(Participant)

Another added:

'It is not easy for an adult to talk to teenagers about sex; culture does not allow this. So if an adult starts to talk to me about sex one needs to be careful as these are people that can easily rape you, you know teenagers always prefer that adults who want to engage teenagers in sexual health dialogue should be people known and trusted by us.'

(Participant)

Some teenagers also indicated that adult information was not reliable because most of the time, the adults who were open about sexual health dialogue were promiscuous or unknown to them. It was therefore noted that if the attitudes of teenagers towards the person who taught them about sexual health was negative, it would be almost impossible for them to engage in dialogue successfully.

\section{Adult information is reliable and correct}

Research amongst Malaysian boys on sexual issues has shown that they would feel comfortable if their parents would talk to them about these issues (Wah-Yun et al. 2007:290). This is contrary to the research conducted by Ogle et al. (2008:286), who found that adolescents were not willing to discuss sexual health matters with their parents and were embarrassed about this. Discussing intercourse with parents was said to be impossible. It was reported that communication on sexual health between adolescents and parents did not commonly take place because adolescents preferred to obtain information from youth workers or medical students (Ogle et al. 2008:287).

Some teenagers expressed their approval at an older person teaching them about sexual health and indicated that there was no way that an older person would mislead them, especially if it was their parent or relative. The parent was regarded as an experienced person who had also passed through that 'difficult' time. Some respondents also felt that it would be wrong to rely only on information that they got from friends and magazines, and observed that most of the time the information that they got from friends was not correct, or was misleading. One participant expressed his views as follows:

'You know, parents want us to have good things, they always expect us to be obedient and succeed in life; there is no way that they can mislead us. Most of the time when they scold us and tell us not to engage in sexual intercourse, our parents want to protect us. I have seen this at home, my sister used not to listen to them now she is having a baby without a father. Now my parents have the burden of looking after her child. That also taught me a lesson and I will listen to my parents.'

(Participant)

Another respondent said:

'Friends can easily mislead you. Sometimes friends can tell you a method of preventing pregnancy that is not proven. Most of the time you will find that the person that is advising you has a child and I always wonder why the method has failed with her. This shows you that this person wants you to have a baby like her.'

(Participant)

\section{Views about how dialogue on sexual health can be initiated}

Teenagers mentioned ways in which dialogue could be initiated between them and parents and/or teachers, (1) discussions should start early at home and (2) they should be taught by people familiar to them.

\section{Discussions should start early at home}

The participants felt that discussions about sexual health should start early in their life before they begin having sex or even menstruating. The teenagers also indicated that sexual health education should be introduced to them by the person within the family who has a role of educating children about sexual health. It was also felt that parents should initiate sexual health education early at home so that by the time they started menstruating or accessing information from peers at school, they would have been exposed to such information in class or at home. One respondent noted: 
'You know, sexual health education should start early in life. The information will help a lot of children to deal with issues such as rape, incest, eeee! I mean this information will also help us to ask relevant questions [when] we become teenagers. You know, by the time a child becomes a teenager he or she will be at ease in engaging adults in sexual health discussions.'

(Participant)

Contrary to this, teenagers in a study about worksitebased parenting reported that they didn't like talking to their parents about sex as it made them feel embarrassed, uncomfortable and nervous (Eastman et al. 2005:66). The participants believed that when they spoke to their parents about sex, their parents would get worried and nervous, thinking that they were now engaging in sexual intercourse (Eastman et al. 2005:66).

\section{Sexual health should be taught by a familiar person}

The participants felt that they would appreciate it if the person teaching them about sexual health was familiar to them, that they knew and trusted, such as family members. It was also found that teenagers were afraid of talking to unfamiliar people because of a fear of sexual abuse. One respondent commented:

'It is very difficult for us to trust information that is given to us by a person who is unfamiliar to us. Let me give you this example: If a teacher teaches you about issues of sexual health sometimes you doubt his intention. Hey! Some of them want to sleep with you, so I don't trust such information. It's better if it is a lady teacher, as they are harmless. Strangers like male nurses, ha! I am afraid.'

(Participant)

\section{Conclusion and recommendations}

Our results indicate that there was a general feeling amongst teenagers that sexual health dialogue should be initiated early in their lives. This means that parents should play a primary role in educating their children about sexual health. Teenagers also reported that there was a need to talk about sex with people whom they knew, which meant that they needed to trust those individuals. Parents are therefore urged to take up their role as primary educators and inform their children about sexual health.

It was evident from the interview data that teenagers lacked education about sexual health. It was noted with concern that the participants always referred to sexual health as an act (intercourse) and there was no mention of other aspects such as rape, STIs and physical changes in their bodies.

Cultural values and norms were said to be the reason for a lack of communication between teenagers and parents and/or teachers. According to culture, a relative such as an aunt is expected to provide teenagers with information about issues regarding sexual health. The type of information provided was said to revolve around the sexual act and not sexual health, indicating the need to educate parents and family members. Almost all the participants reported that sexual health dialogue was absent and communication tended to be unilateral, from the side of the aunt, parents and/or initiation schools, with no consideration for the teenagers' opinions. The other source of information, which was the media, also placed emphasis on the sexual act, which meant that sexual health was addressed as an act (intercourse). It should be noted from the study results that the teenagers and parents and/or teachers appear to be ignorant about sexual health. Parents and teachers need more information about sexual health so that they, in turn, can educate teenagers sufficiently and are better able to address questions that may arise.

\section{References}

Adams, J. \& East, P., 2002, 'Sexual assertiveness and adolescent sexual rights. Perspective on sexual and reproductive health', Academic Research Library 34(4), 36-50.

Anwers.com. 2007, viewed 27 July 2007, from http://www.answers.com/topic/ media-ancient-country-of-southwest-asia?cat=travel

Billy, J. \& Undry, J.R., 1985, 'The influence of male best friends on adolescent sexual behaviour', Journal for adolescence 20(77), 21-32.

Brink, H.I., 2000, Fundamentals of research methodology for health professionals, Juta, Cape Town.

Burns, N. \& Grove, S., 2001, The practice of nursing research: Conduct, critique and utilization, W.B. Saunders, Philadelphia.

Cebekhulu, O., Bekisiska, A.S. \& Erulkar, A.S., 2001, An assessment of youth centres in South Africa, The Press Gang, Durban.

Cresswell, J.W., 1994, Research design: Qualitative and quantitative approaches, Sage, London.

DENOSA, 1998, Ethical standards for nurse researchers, DENOSA, Pretoria

Dickson-Tetteth, K. \& Foy, D., 2000, 'The national Adolescent Friendly Clinic Initiative: Handbook of adolescent sexual and reproductive health care', Academic Research Library 23(2), 2-22.

Eastman, K.L., Corona, R. \& Schuster, M.A., 2005, 'Talking parents, healthy teens: A worksite-based program for parents to promote adolescent sexual health', viewed October 2010, from http://apha.confex.com/apha/130am/techprogram/paper

Evans, D.L. \& Tripp, J.H., 2006, 'Sex education: The case for primary prevention and peer education', Journal for current paediatrics 16(7), 95-99.

Grobler, C., Botma, Y., Jacobs, A.C. \& Nel, M., 2007, 'Beliefs of grade six learners regarding adolescent pregnancy and sex', Curationis 30(1), 32-40. PMid:17515314

Halloway, I. \& Wheeler, S., 2002, Qualitative research for nurses, Blackwell Science, Australia.

Hassan, E.A. \& Creatsas, G.C., 2000, 'Adolescent sexuality: A developmental milestone or risk-taking behaviour? The role of health care in the prevention of sexually transmitted diseases', Journal of pediatric gynecology 13(90), 119-124.

Ingham, R. \& Stone, N., 2002, 'Factors affecting British teenagers' contraceptive use at first intercourse. The importance of partner communication. Perspectives on sexual and reproductive health', Academic Research Library 34(4), 45-63.

Jewkes, R., Maforah, F., Jordaan, E. \& Vundulu, C., 2001, 'Relationship dynamics and teenage pregnancy in South Africa', Social Science Medicine 52(2), 733-744. doi:10.1016/S0277-9536(00)00177-5

Kalmus, D., Davidson, A., Cohall, A., Laragus, D. \& Cassell, C., 2003, 'Preventing sexual risk behaviours and pregnancy among teenagers: Linking research and programmes. Perspectives on sexual reproductive health', Academic Research Library 35(2), 734-771.

Kirby, D., 2001, 'Understanding what works and what doesn't in reducing adolescent risk taking. Perspectives on sexual and reproductive health', Academic Research Library 33(6), 61-80.

Kvale, S., 1983 'The qualitative research interview. A phenomenological and a hermeneutical mode of understanding', Journal of Phenomenological Psychology 14(1), 171-196. doi:10.1163/156916283X00090

Leininger, M.M., 1991, Cultural care diversity and universality: A theory for nursing, National League of Nursing, New York.

Lincoln, Y. \& Guba, E., 1985, Naturalistic inquiry, Sage, London.

Malcolm, X., 2007, Media's influence on society, viewed August 2007, from http://www. csnu.edu〜sm60012/GRCS\%20Files/Final\%20Projects/Medialnfluenceonsociety

Maluleke, T.X., 2007, 'The youths' perceptions of sexuality in the Limpopo Province of South Africa', Health SA Gesondheid 12(3), 3-16.

Mavundla, T.R. \& Williams, C.X., 1999, 'Teenage mothers' knowledge of sex education in a general hospital of Umtata district', Curationis 22(1), 58-63. PMid:11040611

Mbugua, N., 2006, 'Factors inhibiting educated mothers in Kenya from giving meaningful sex-education to their daughters', Social Science and Medicine 64(5), 1079-1089. doi:10.1016/j.socscimed.2006.10.008 
Mdluli, M., 2005, A psycho-educational model for facilitation of self discipline for educators in rural township schools, RAU, Johannesburg.

Mfono, Z., 1998, 'Teenage contraceptive needs in urban South Africa: A case study. International family planning perspective', Proquest Nursing Journals 24(4), 2248.

Mouton, J. \& Marais, J.C., 1990, Basic concepts in methodology of the social science. Pretoria: Human Science Research council. Methodology of the social sciences: Basic concepts, Human Sciences Research Council, Johannesburg.

Mulaudzi, F.M., 2007, 'Indigenous health beliefs, attitudes and practices among Vhavhenda: A challenge to the promotion of HIV/AIDS prevention strategies' Curationis 3(3), 34-35.

Ogle, S., Glasier, A. \& Riley, S.C., 2008, 'Communication between parents and their children about sexual health', Journal for contraception $77(10)$, 283-288. doi:10.1016/j.contraception. 2007.12.003, PMid:18342652
Polit, D.F. \& Hungler, B.P.P., 2004, Nursing research: Principles and methods, JB Lippincot, Philadelphia.

Vuttanont, U., Greenhaigh, T.G.M., Griffin, M. \& Boyton, P., 2006, "'Smart boys and sweet girls" sex education needs in Thai teenagers: A mixed method study', The Lancet 363(9552), 2068-2080. doi:10.1016/S0140-6736(06)69836-X

Wah-Yun, L., Chirk-Jenn, N.G., Sohaimi, F.K., Fadzil, K.S. \& Eng-Suan, A.N.G., 2007 'Sexual issues: Let's hear it from the Malaysian boys', The Journal of Men's Health and Gender 4(3), 283-291. doi:10.1016/j.jmhg.2007.04.010

Wood, K., Maforah, F. \& Jewkes, R. 1998 “"He forced me to love him”: Putting violence on adolescent sexual health agendas', Social Science Medicine 47(2), 233-242. doi:10.1016/S0277-9536(98)00057-4 